\title{
Territorial distribution and quality indicators of compulsory Neonatal Hearing Screening in Brazil after Law 12,303/2010
}

\author{
Georgea Espindola Ribeiro' \\ https://orcid.org/0000-0003-3969-5252 \\ Silke Anna Theresa Weber ${ }^{1}$ \\ https://orcid.org/0000-0003-3194-3039 \\ Daniela Polo Camargo da Silva ${ }^{2}$ \\ https://orcid.org/0000-0003-2082-9361
}

Universidade Estadual Paulista - UNESP, Faculdade de Medicina de Botucatu, Departamento de Oftalmologia, Otorrinolaringologia e Cirurgia Cabeça e Pescoço, Botucatu, São Paulo, Brasil.

2 Universidade Federal de Santa Catarina UFSC, Departamento de Fonoaudiologia, Florianópolis, Santa Catarina, Brasil.

Conflict of interests: Nonexistent

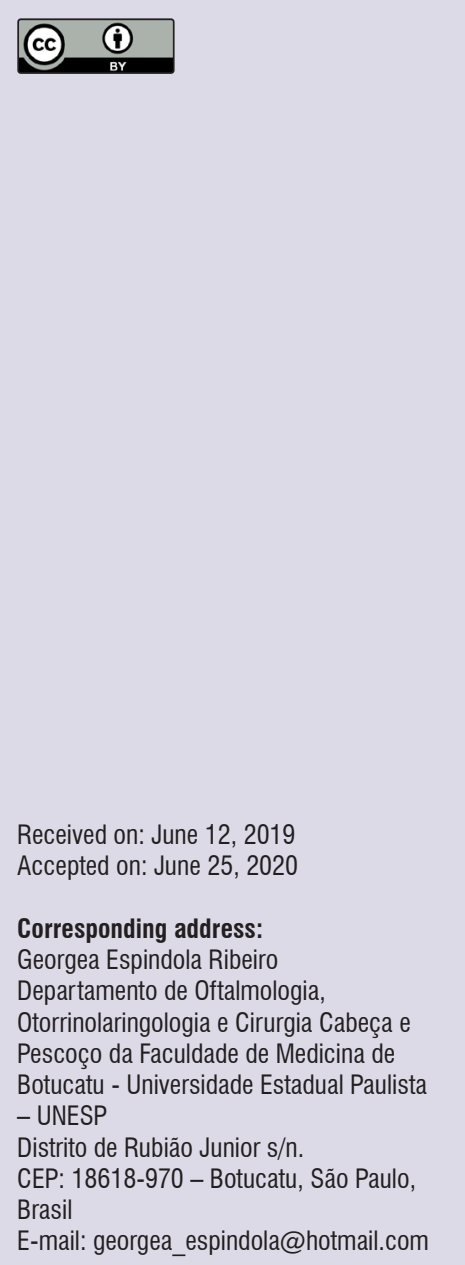

\section{ABSTRACT}

Purpose: to survey the national literature after the universal neonatal hearing screening became compulsory, addressing aspects related to its territorial distribution, the screening procedures employed, and verify whether the internationally proposed quality indicators have been achieved.

Methods: an integrative review of articles indexed in the BIREME, PubMed, and Scopus databases. Inclusion criteria: Articles in Portuguese and English published after Law $12,303 / 2010$ was passed, whose theme was the neonatal hearing screening in Brazil. Exclusion criteria: Information from books and/or chapters, integrative review articles or reflexive articles, studies conducted in other countries, and studies approaching a specific subpopulation. The search strategy combined the following descriptors in Portuguese and English, respectively: "Triagem Neonatal", "Perda auditiva", "Recémnascido", "Brasil”, "Neonatal Screenings", "Hearing Loss", "Newborn”, "Brazil”.

Results: of the 224 articles found, 26 were duplicates, 38 were books or book chapters, three were integrative reviews, 20 were studies conducted in other countries, and 120 were either reflexive articles or studies approaching a specific subpopulation. The final sample comprised 17 articles that addressed the proposed theme.

Conclusion: the South and Southeast Regions of Brazil concentrated most of the programs, and the main technique employed was the evoked otoacoustic emissions. Two quality indicators were achieved: performance rates within the first month of life, and diagnosis referral rates. However, the coverage rates remained below the expectation, and there were still high retest referral rates, high nonattendance rates in the subsequent stages, low satisfactory retest result rates, and a large number of "fail" in the two screening stages.

Keywords: Neonatal Screening; Hearing Loss; Newborn; Brazil 


\section{INTRODUCTION}

Hearing is the sense through which people acquire oral language. Such a function follows steps of increasing complexity, beginning in intrauterine life. For children to learn to speak, they must be capable of detecting, localizing, discriminating, recognizing, and finally understanding the sounds ${ }^{1}$. Failing to develop any of these auditory skills causes important functional impairments to the child. It is essential, then, that auditory problems be detected soon after birth, even if no potential risks for their occurrence have been identified in the clinical history ${ }^{2,3}$.

The detection of hearing loss is part of the universal neonatal hearing screening program (UNHS), performed with electroacoustic/electrophysiological procedures. It must be carried out before the baby is one month old, preferably before hospital discharge. In cases of "fail" in the initial test or retest, the neonate must undergo an adequate medical and audiological assessment before they are three months old to confirm the hearing loss. Also, they must start intervention by six months old, following recommendations from the Joint Committee on Infant Hearing $(\mathrm{JClH}$, 2007) ${ }^{2}$. However, the new JClH publication (2019) ${ }^{4}$ suggests that the hearing loss early identification and intervention programs that already comply with this goal start considering diagnosis by two months old and intervention by three months old. Hence, the goal, which used to be 1-3-6, becomes 1-2-3 months of life.

Before creating this program, hearing loss in newborns was identified with a behavioral hearing assessment with uncalibrated sound stimuli. Most of the time, it encompassed only individuals with risk indicators 5 . Thus, newborns not included in such criteria were neglected, not having their hearing deficit recognized. This caused them serious socioemotional impacts and greater financial overload for the government, because of the late detection ${ }^{6}$. In the absence of early detection programs, the severe and profound hearing loss diagnoses in developed countries take place when the baby is two and a half to three years old. In developing countries, such as Brazil, the situation is even more critical, ranging from two to seven years ${ }^{6}$.

In September 2004, the regulatory law no. 2,073 was promulgated, establishing the National Auditory Health Care Policy. Its purpose is to enforce auditory health promotion actions, encompassing various aspects, namely: prevention; early identification and intervention of auditory problems (which must be carried out in primary health care and medium- and high-complexity services); and educative initiatives for the families ${ }^{7}$. In 2012, the Neonatal Hearing Screening Care Guidelines were issued, which were developed by a group of scientific institutions to make guidelines available to the multi-professional teams regarding the auditory health care in childhood, particularly the neonatal hearing screening ${ }^{8}$. They enabled the population to have access to all the health procedures, of which the UNHS is the starting point that leads to the whole auditory care, essential to the success of all subsequent stages ${ }^{6-8}$.

In Brazil, the UNHS became compulsory in 2010 with the law 12,303 , making it available to all the children born in public hospitals or maternities nationwide. This led to advances in the context of child health care ${ }^{9}$. In the same year, the Auditory health Multiprofessional Committee (COMUSA, in Portuguese) ${ }^{3}$ improved the requirements for performing the UNHS, including in the recommendations the implementation of quality indicators ${ }^{2,4}$ to assess the actions being taken to provide comprehensive auditory health care to children. Its instructions included that the UNHS should cover at least $95 \%$ of live births, aiming to reach $100 \%$; that they be screened no later than the first month of life; that the diagnosis referral rate be lower than $4 \%$; that $90 \%$ of the referred neonates should adhere to the diagnosis stage; and that $95 \%$ of the infants with confirmed permanent hearing loss in both ears should start using hearing aid within a month from diagnosis.

The recent $\mathrm{JCIH}$ publication ${ }^{4}$ recommends also that the services indicate the percentage of neonates who were screened within their first month of life; those who did not pass the initial screening; who needed retest; who did not pass the test-retest stages; and those who did not pass the initial screening, but did pass the retest.

Moreover, given the continental size of Brazil with its regional, economic, social, health, and cultural diversity, the approach to implementing UNHS programs can differ from place to place. Therefore, it is essential to present the current situations of the programs and, in this regard, contextualize the country in the international sphere. The goal is to lead to a reflection on the national scenario of child hearing loss early identification, which is essential to create efficient new programs that above all can adapt the identification process to the various regions.

Thus, this article aimed to survey the national literature after the obligation to perform the UNHS, approaching aspects related to territorial distribution, 
and procedures adopted for screening, as well as verify whether the internationally proposed quality indicators ${ }^{4}$ were achieved throughout these years ${ }^{2,4}$.

\section{METHODS}

This is an integrative literature review with a methodological approach, allowing various types of research to be included, leading to conclusions in this specific field of study.

These were the steps followed in the integrative literature review: identification of the problem (the purpose of the review was clearly defined); search for the literature (delimiting keywords and database, and using the article selection criteria); evaluation, and analysis of the data obtained.

The studies were searched from June to July 2018. The inclusion criteria were articles in Portuguese and English, published after the law 12,303/2010 was passed, and whose theme was the neonatal hearing screening in Brazil.

The articles were searched in the PubMed and Scopus databases, using the Health Sciences Descriptors (DeCS) and Medical Subject Headings (MeSH).

The search strategy combined the following descriptors in Portuguese and English, respectively: "Triagem Neonatal", "Perda auditiva", "Recémnascido", "Brasil", "Neonatal Screenings", "Hearing Loss", "Newborn", "Brazil". The studies approached screening procedures in Brazil, age at the time of the examination, and the estimates of UNHS pass/fail result rates. The methodology used in the studies was not a selection criterion for this review.

The following were excluded from the study: Information from books and/or chapters, integrative review articles, reflexive articles, studies carried out in other countries, and studies with a specific subpopulation - i.e., when the main approach was not the UNHS, but the association of risk indicators or other aspects in the result of the examinations.

The instrument developed to extract and analyze the data from the studies comprised the following items: (1) Does the text approach UNHS in Brazil? If so, how is it performed? (2) Does it point out the risk indicators for hearing loss in the sample? (3) Are the internationally proposed quality indicators being achieved?

The screening quality indicators verified in the studies covered information on screening coverage rates, neonate's age at the time of the test, retest referral and attendance rates, satisfactory results in the retest, unsatisfactory results in the test-retest, and diagnosis referral rates ${ }^{2,4}$.

The stages of extraction and analysis of the results of the primary studies were carried out by two teams of revisors, who worked independently.

The data extracted from the articles were submitted to descriptive analysis and summary. Hence, they were observed, counted, described, and classified, to gather the knowledge produced regarding the theme approached in this review.

\section{LITERATURE REVIEW}

Following identification, the primary studies were selected based on the preestablished research question and inclusion criteria. A total of 224 publications were found in the search strategy - 38 of them from PubMed, 29 from Bireme, and 157 from Scopus. All the studies identified with the search strategy had their titles and abstracts initially analyzed. Whenever the titles and abstracts were not sufficient to define whether to include the publications, these had to be read in full. While still in the selection stage, the authors met to reach a consensus regarding the selected articles, thus minimizing the risk of bias.

Of the 224 articles found, 26 were duplicated, 38 were books or chapters approaching the theme in question, three were integrative reviews, 20 were studies conducted in other countries, and 120 were reflective articles or studies with a specific subpopulation.

The final sample comprised 17 articles published between 2010 and 2017, with the following information: number of screened neonates, the technique employed, age, screenings conducted before hospital discharge, coverage of the programs, percentage of satisfactory results in the initial test and retest, risk indicators, percentage of absenteeism, diagnosis referrals, and percentage of diagnosed hearing loss (Figure 1). 


\begin{tabular}{|c|c|c|c|c|c|c|c|c|c|c|c|}
\hline Reference & $\begin{array}{l}\begin{array}{l}\text { Number } \\
\text { of } \\
\text { screened } \\
\text { neonates }\end{array} \\
\end{array}$ & Technique & Age & $\begin{array}{c}\text { UNHS } \\
\text { before } \\
\text { hospital } \\
\text { discharge }\end{array}$ & $\begin{array}{l}\text { UNHS } \\
\text { coverage }\end{array}$ & $\begin{array}{l}\text { Percentage } \\
\text { of "pass" } \\
\text { results in } \\
\text { the initial } \\
\text { assessment }\end{array}$ & $\begin{array}{l}\text { Percentage } \\
\text { of "pass" in } \\
\text { the retest }\end{array}$ & $\begin{array}{l}\text { Risk indicators for } \\
\text { hearing loss }\end{array}$ & Absenteeism & $\begin{array}{l}\text { Referrals for } \\
\text { diagnosis }\end{array}$ & $\begin{array}{c}\text { Hearing loss } \\
\text { diagnosis }\end{array}$ \\
\hline $\begin{array}{c}\text { Sabbag et.al } \\
2017^{12} \\
\text { Curitiba } \\
\text { PR }\end{array}$ & 50 & TEOAE & $\begin{array}{l}92 \% \text { before } \\
\text { hospital } \\
\text { discharge }\end{array}$ & Yes & $N / R$ & $94 \%$ & $67 \%$ & \begin{tabular}{|c|} 
ICU, craniofacial \\
malformation, prematurity, \\
psychotropic drug use \\
during the pregnancy \\
\end{tabular} & $0 \%$ & $2 \%$ & $0 \%$ \\
\hline $\begin{array}{c}\text { Januário et.al } \\
2016^{13} \\
\text { Belo } \\
\text { Horizonte } \\
\text { MG } \\
\end{array}$ & 4,442 & $\begin{array}{l}\text { TEOAE, } \\
\text { BOA }\end{array}$ & $\begin{array}{l}64.3 \% \text { up to } \\
30 \text { days old }\end{array}$ & No & $\mathrm{N} / \mathrm{R}$ & $92.7 \%$ & $63.29 \%$ & $\mathrm{~N} / \mathrm{R}$ & $25.6 \%$ & $1.9 \%$ & $\mathrm{~N} / \mathrm{R}$ \\
\hline $\begin{array}{c}\text { Biscegli et al. } \\
2015^{14} \\
\text { Catanduva } \\
\text { SP }\end{array}$ & 587 & TEOAE & $\begin{array}{l}90 \% \text { up to } \\
\text { one month } \\
\text { old }\end{array}$ & No & $51.3 \%$ & $95.6 \%$ & $\mathrm{~N} / \mathrm{R}$ & $\begin{array}{l}\text { birth weight }<1,500 \\
\mathrm{~g} \text {, low Apgar score, } \\
\text { MV, prolonged stay in } \\
\text { an incubator, ototoxic } \\
\text { medication use, and } \\
\text { Hyperbilirubinemia }\end{array}$ & $\mathrm{N} / \mathrm{R}$ & $\mathrm{N} / \mathrm{R}$ & $N / R$ \\
\hline $\begin{array}{c}\text { Barboza et al. } \\
2013^{15} \\
\text { Belo } \\
\text { Horizonte } \\
\text { MG } \\
\end{array}$ & 3,151 & $\begin{array}{c}\text { TEOAE, } \\
\text { BAEP, BOA }\end{array}$ & $\begin{array}{l}\text { At least } 15 \\
\text { days old, } \\
\text { mean } 64 \\
\text { days old }\end{array}$ & No & $N / R$ & \begin{tabular}{|c|}
$87.1 \%$ \\
without RI \\
$72.6 \%$ with RI
\end{tabular} & $\begin{array}{c}67.37 \% \\
\text { without RI } \\
55.94 \% \\
\text { with Rl }\end{array}$ & \begin{tabular}{|} 
ICU, ototoxic medication \\
use, MV, and suspicion for \\
a genetic syndrome
\end{tabular} & $\begin{array}{c}35 \% \\
\text { without RI } \\
35 \% \text { with RI }\end{array}$ & $\begin{array}{c}2.59 \% \\
\text { without RI } \\
7.8 \% \text { with RI }\end{array}$ & $1.97 \%$ \\
\hline $\begin{array}{c}\text { Oliveira et al } \\
2013^{16} \\
\text { Porto Velho } \\
\text { RO }\end{array}$ & 1,146 & $\begin{array}{l}\text { TEOAE, } \\
\text { BAEP }\end{array}$ & $\begin{array}{l}\text { Up to one } \\
\text { month old }\end{array}$ & No & $N / R$ & $92.8 \%$ & $\mathrm{~N} / \mathrm{R}$ & $\begin{array}{l}\text { ICU, ototoxic medication, } \\
\mathrm{HL} \text { in the family, } \\
\text { craniofacial anomaly, the } \\
\text { mother with malaria, } \mathrm{Cl}\end{array}$ & $\mathrm{N} / \mathrm{R}$ & $7.15 \%$ & $0.2 \%$ \\
\hline $\begin{array}{l}\text { Cavalcanti } \\
\text { et al. } \\
2012^{17} \\
\text { Natal } \\
\text { RN }\end{array}$ & 3,724 & TEOAE & $\begin{array}{l}\text { Within } 36 \\
\text { and } 48 \\
\text { hours from } \\
\text { birth }\end{array}$ & Yes & $69.9 \%$ & $84.5 \%$ & $81.30 \%$ & $\begin{array}{c}\text { HL in the family, } \\
\text { consanguinity, drug } \\
\text { use during pregnancy, } \\
\text { ototoxic medication, } \\
\text { Cl, syndromes, and } \\
\text { craniofacial anomalies. }\end{array}$ & $38.8 \%$ & $1.77 \%$ & $N / R$ \\
\hline $\begin{array}{c}\text { Faistauer } \\
\text { et al. } \\
2012^{18} \\
\text { Porto Alegre } \\
\text { RS }\end{array}$ & 2,165 & TEAOE & $\begin{array}{c}\text { Before } \\
\text { hospital } \\
\text { discharge }\end{array}$ & Yes & $N / R$ & $83 \%$ & $96 \%$ & \begin{tabular}{|c|} 
ICU, craniofacial \\
malformation, \\
syndromes, family history \\
of congenital hearing \\
loss, neonatal infections, \\
hyperbilirubinemia, and \\
weight $<1,500 \mathrm{~g}$. \\
\end{tabular} & $24 \%$ & $0.55 \%$ & $1 \%$ \\
\hline $\begin{array}{l}\text { Onoda et al. } \\
2011^{11} \\
\text { São Paulo } \\
\text { SP }\end{array}$ & 1,805 & $\begin{array}{l}\text { TEOAE, } \\
\text { BOA }\end{array}$ & $\begin{array}{l}\text { Around } 48 \\
\text { hours after } \\
\text { birth }\end{array}$ & Yes & $39.3 \%$ & $74.7 \%$ & $89 \%$ & $\begin{array}{c}\text { HL in the family, } \\
\text { malformation, ototoxic } \\
\text { medication, MV, PIVH, } \\
\text { ICU, birth weight }<1,500 \mathrm{~g}\end{array}$ & $13 \%$ & $1.7 \%$ & $0.5 \%$ \\
\hline $\begin{array}{l}\text { Rodrigues } \\
\text { et al. } \\
2011^{19} \\
\text { Cuiabá MT }\end{array}$ & 2,087 & TEAOE & $\begin{array}{l}\text { Median } \\
12 \text { days } \\
\text { (minimum } \\
2 \text { and } \\
\text { maximum } \\
90 \text { days) } \\
\end{array}$ & $\begin{array}{l}\text { Only for } \\
\text { neonates } \\
\text { with RI }\end{array}$ & $N / R$ & $\begin{array}{c}91.24 \% \\
\text { without Rl } \\
65.85 \% \\
\text { with Rl }\end{array}$ & $\begin{array}{c}94.50 \% \\
\text { without RI } \\
71.54 \% \\
\text { with RI }\end{array}$ & $\mathrm{N} / \mathrm{R}$ & $\begin{array}{c}4.28 \% \\
\text { without } \mathrm{Rl} \\
25.21 \% \\
\text { with } \mathrm{Rl}\end{array}$ & $\mathrm{N} / \mathrm{R}$ & $N / R$ \\
\hline $\begin{array}{l}\text { Botelho et al. } \\
2010^{20} \\
\text { Porto Velho } \\
\text { R0 }\end{array}$ & 6,889 & TEOAE & $\begin{array}{l}\text { Within } 24 \\
\text { hours from } \\
\text { birth }\end{array}$ & Yes & $N / R$ & $82.7 \%$ & $N / R$ & $\begin{array}{l}\text { Hyperbilirubinemia, } \\
\text { anoxia, craniofacial } \\
\text { malformation, } \mathrm{HL} \text { in } \\
\text { the family, birth weight } \\
<1,500 \mathrm{~g} \text {, syndrome, } \\
\text { and Cl }\end{array}$ & $24.3 \%$ & $\mathrm{~N} / \mathrm{R}$ & $0.22 \%$ \\
\hline $\begin{array}{l}\text { Lima et al. } \\
2015^{21} \\
\text { Campinas } \\
\text { SP }\end{array}$ & 14,205 & TEOAE & $\begin{array}{c}\text { Mean } 15 \\
\text { days }\end{array}$ & No & $85 \%$ & $92.64 \%$ & $83.85 \%$ & $N / R$ & $8.69 \%$ & $1.2 \%$ & $0.49 \%$ \\
\hline $\begin{array}{l}\text { Kemp et al. } \\
2015^{22} \\
\text { Marília } \\
\text { SP }\end{array}$ & 645 & $\begin{array}{l}\text { TEOAE, } \\
\text { DPOAE, } \\
\text { BAEP }\end{array}$ & $\begin{array}{l}\text { Mean } 14 \\
\text { days old }\end{array}$ & No & $96.3 \%$ & $98.50 \%$ & $13.33 \%$ & $\begin{array}{c}\text { Hyperbilirubinemia, } \\
\text { HL in the family, ICU, } \\
\text { ototoxic medication, Cl, } \\
\text { craniofacial anomaly, } \\
\text { syndrome, and blood } \\
\text { transfusion } \\
\end{array}$ & $0.93 \%$ & $1.55 \%$ & $0.62 \%$ \\
\hline $\begin{array}{l}\text { Silva et al. } \\
2015^{23} \\
\text { Marília } \\
\text { SP }\end{array}$ & 579 & $\begin{array}{l}\text { TEOAE, } \\
\text { DPOAE }\end{array}$ & $\begin{array}{l}\text { Between } \\
6 \text { and } 54 \\
\text { days }\end{array}$ & No & $\mathrm{N} / \mathrm{R}$ & $\begin{array}{c}95.16 \%- \\
\text { TEOAE } \\
91.54 \%- \\
\text { DPOAE }\end{array}$ & $\mathrm{N} / \mathrm{R}$ & There were no Rl & $\mathrm{N} / \mathrm{R}$ & $N / R$ & $N / R$ \\
\hline
\end{tabular}




\begin{tabular}{|c|c|c|c|c|c|c|c|c|c|c|c|}
\hline Reference & $\begin{array}{c}\text { Number } \\
\text { of } \\
\text { screened } \\
\text { neonates }\end{array}$ & Technique & Age & $\begin{array}{c}\text { UNHS } \\
\text { before } \\
\text { hospital } \\
\text { discharge }\end{array}$ & $\begin{array}{l}\text { UNHS } \\
\text { coverage }\end{array}$ & $\begin{array}{l}\text { Percentage } \\
\text { of "pass" } \\
\text { results in } \\
\text { the initial } \\
\text { assessment }\end{array}$ & $\begin{array}{l}\text { Percentage } \\
\text { of "pass" in } \\
\text { the retest }\end{array}$ & $\begin{array}{l}\text { Risk indicators for } \\
\text { hearing loss }\end{array}$ & Absenteeism & $\begin{array}{c}\text { Referrals for } \\
\text { diagnosis }\end{array}$ & $\begin{array}{c}\text { Hearing loss } \\
\text { diagnosis }\end{array}$ \\
\hline $\begin{array}{l}\text { Silva et al. } \\
2015^{24} \\
\text { Botucatu } \\
\text { SP }\end{array}$ & 565 & TEOAE & $\begin{array}{c}\text { Before } \\
\text { hospital } \\
\text { discharge }\end{array}$ & Yes & $\mathrm{N} / \mathrm{R}$ & $59.0 \%$ & $92.12 \%$ & $\begin{array}{l}\text { Low Apgar, birth weight } \\
<1,500 \mathrm{~g}, \mathrm{ICU}, \mathrm{MV}, \mathrm{Cl} \text {, } \\
\text { ototoxic medication, drug } \\
\text { use during pregnancy, } \\
\text { craniofacial malformation, } \\
\text { and } \mathrm{HL} \text { in the family }\end{array}$ & $30 \%$ & $2.3 \%$ & $\mathrm{~N} / \mathrm{R}$ \\
\hline $\begin{array}{l}\text { Januário } \\
\text { et al. } \\
2015^{25} \\
\text { Belo } \\
\text { Horizonte } \\
\text { MG } \\
\end{array}$ & 6,987 & $\begin{array}{l}\text { TEOAE, } \\
\text { BOA }\end{array}$ & $\begin{array}{l}\text { After } \\
\text { hospital } \\
\text { discharge } \\
\text { median } 23 \\
\quad \text { days }\end{array}$ & No & $\mathrm{N} / \mathrm{R}$ & $92 \%$ & $62.6 \%$ & $\begin{array}{l}\mathrm{HL} \text { in the family, ICU, } \\
\mathrm{MV} \text {, ototoxic medication, } \\
\mathrm{Cl} \text {, craniofacial anomaly, } \\
\text { genetic syndromes, } \\
\text { neurodegenerative } \\
\text { diseases, bacterial or } \\
\text { post-viral infections }\end{array}$ & $\begin{array}{c}22.4 \% \\
\text { without RI } \\
5.7 \% \text { with RI }\end{array}$ & $2.1 \%$ & $\mathrm{~N} / \mathrm{R}$ \\
\hline $\begin{array}{l}\text { Lupoli et al. } \\
2013^{26} \\
\text { Ribeirão } \\
\text { Preto } \\
\text { SP }\end{array}$ & 890 & TEOAE & $\begin{array}{c}\text { Before } \\
\text { hospital } \\
\text { discharge } \\
\text { within } 24 \text { to } \\
48 \text { hours }\end{array}$ & Yes & $\mathrm{N} / \mathrm{R}$ & $70 \%$ & $\mathrm{~N} / \mathrm{R}$ & There were no RI & $\mathrm{N} / \mathrm{R}$ & $N / R$ & $\mathrm{~N} / \mathrm{R}$ \\
\hline $\begin{array}{l}\text { Bevilacqua } \\
\text { et al. } \\
2010^{27} \\
\text { Bauru } \\
\text { SP }\end{array}$ & 11,466 & TEOAE & $\begin{array}{l}\text { Within } 24 \\
\text { hours from } \\
\text { birth, or } 20 \\
\text { days after } \\
\text { birth at the } \\
\text { most }\end{array}$ & Yes & $90.52 \%$ & $77.8 \%$ & $81.30 \%$ & $\begin{array}{l}\mathrm{HL} \text { in the family, } \\
\text { prolonged stay in the ICU, } \\
\text { mechanical ventilation } \\
\text { use, and ototoxic } \\
\text { medication use }\end{array}$ & $19.7 \%$ & $3.33 \%$ & $0.47 \%$ \\
\hline
\end{tabular}

HL: hearing loss; TEOAE: transient-evokes otoacoustic emissions; BOA: behavioral observation audiometry; BAEP: brainstem auditory evoked potentials; DPOAE: distortion-product otoacoustic emissions; N/R: not reported; ICU: intensive care unit; RI: risk indicator; HL: hearing loss; MV: mechanical ventilation; Cl: congenital infection; PIVH: peri-intraventricular hemorrhage; low Apgar: one-minute Apgar $<4$ and/or five-minute Apgar $<6$.

Figure 1. Description of the UNHS in Brazil after the law 12,303, number of screened neonates, the technique employed, age, screening performed before hospital discharge, coverage of the programs, percentage of "pass" results in the initial assessment and retest, risk indicators, percentage of absenteeism, diagnosis referrals, and percentage of diagnosed hearing loss

In Brazil, the hearing loss early identification programs are being developed since 1987 in neonates with and without risk of hearing loss - initially with behavioral measures, and afterward with objective measure ${ }^{10}$. In the last years, there has been a significant increase in the number of auditory screening services, especially after $2010^{11}$.

This review's approach of verifying auditory screening in the country after the law 12,303/2010 revealed that most of the publications were from the South and Southeast Regions, while few reports from these programs come from the North, Northeast, and Central-West Regions of Brazil ${ }^{11-27}$.

Brazil has 277 neonatal auditory screening services accredited by the Sistema Único de Saúde (Brazilian Public Health Care System) - 29 programs in the North, 52 in the Northeast, 19 in the Midwest, 124 in the Southeast, and 53 in the South ${ }^{28}$.

Such a difference can be justified by Brazil's demographic and socioeconomic heterogeneity, besides the pioneer implementation of the National
Auditory Health Care Policy in the South and Southeast Regions ${ }^{29}$. Another reason is the high concentration of medium- and high-complexity services in these regions. These are important, as they not only perform the screening but also provide the following stages of the program $^{28,29}$. The availability of qualified professionals is another contributing factor, as these regions concentrate the highest number of speech-language-hearing therapists in the country, reinforcing the uneven distribution in the Brazilian territory ${ }^{29}$.

The speech-language-hearing therapist is the professional responsible for conducting the UNHS. An uneven distribution, along with an insufficient number of professionals in the public health system, can be another element reflected in the low estimates of UNHS coverage in Brazil and the disparities observed. It is reasonable to infer that the various factors related to the unequal access to health are echoed in child auditory health.

Hence, equity and comprehensiveness in health are challenging aspects, which depend on local initiatives 
and measures. The state and municipal administrations should take these steps, according to the financial situation and the needs of the population ${ }^{30}$.

Compared with the developed countries, the developing ones, Brazil included, have a clear difficulty in implementing hearing loss early detection and intervention programs. To improve the quality of the UNHS in Brazil, it is essential to evaluate how these programs work, whether the measures used effectively reveal the prevalence of hearing loss, and what the coverage of these programs is ${ }^{31}$.

The reading of the articles showed that the transientevoked otoacoustic emissions were the initial and main procedure to screen newborns with and without risk of hearing loss, followed by retest within 15 to 30 days, with the BAEP in subsequent stages, or referral to diagnosis services (Figure 1).

The otoacoustic emissions exam has high sensitivity to verify cochlear integrity. However, it is not an examination recommended in cases of newborns with risk indicators for hearing loss because this population is more likely to have retrocochlear alteration ${ }^{5}$.

Therefore, in 2007 the $\mathrm{JClH}^{2}$ started recommending the inclusion of the automated BAEP in neonates who stayed in neonatal ICU for more than five days. The Neonatal Hearing Screening Care Guidelines ${ }^{8}$ and the recent $2019 \mathrm{JClH}$ publication ${ }^{4}$ maintain this instruction for infants with risk indicators for hearing loss, so that neural hearing losses will not go unnoticed. Nevertheless, in most services, it is conducted only after persistent fails in the otoacoustic emissions examination (Figure 1). This can be explained by the lack of BAEP equipment in the maternities, the higher cost of this procedure, and the longer time it requires to be performed ${ }^{2}$.

Regarding the methods complementary to the UNHS, the cochlear-palpebral reflex research is a behavioral response present in $90 \%$ to $100 \%$ of the individuals with normal hearing ${ }^{11}$. The absence of a cochlear-palpebral reflex associated with the presence of responses in the otoacoustic emissions exam may indicate retrocochlear alteration ${ }^{11}$. Nonetheless, only four studies reported the use of this research.

The most-reported risk indicators for hearing loss were the use of ototoxic medication, the stay in the intensive care unit for more than five days, the presence of craniofacial anomalies, cases of hearing loss in the family, and the use of mechanical ventilation ${ }^{11-27}$ (Figure 1).
Moreover, the $\mathrm{JClH}^{2,4}$ recommends that the health services follow up the auditory and language development of the neonatal population, regardless of the results in the UNHS, to identify progressive and/or lateonset losses. It is necessary to constantly monitor the neonates with risk indicators for hearing loss, which should be extended at least until they are nine months old.

It is recommended that the UNHS be performed in the first month of life 2,4 - the Federal Law no. 12,303 of $2010^{9}$ stipulates that it take place before the discharge, within 24 to 48 hours from birth. However, the national studies show that not all services manage to reach this goal, as some programs do not work inside the maternity - i.e., they receive children from various places with referrals for screening. There were also clinical difficulties to carry out the exam in children at risk within the established time. Nevertheless, the 17 studies in this review sought to assess most of the neonates within a month of life. Now there are greater challenges due to the new stipulations, such as the time for diagnosis reduced to two months, and the intervention to three months old ${ }^{4}$.

Of the studies included, only one met the UNHS coverage criteria, which was higher than $95 \%{ }^{22}$. In the other programs, the coverage ranged from $90.52 \%$ to $39.3 \%{ }^{11-27}$. The impossibility to carry out the procedure in all the newborns is justified by such factors as not performing it before the discharge, death, transfer, and even refusal. Another issue is the importance of performing the screening daily, including holidays and weekends.

Regarding the rate of neonates who failed the initial screening and were referred for the retest, the studies showed a mean rate of $15.7 \%$ (a minimum of $1.5 \%$ and a maximum of $41 \%)^{11-27}$. The high "fail" rates may be related to the time when the screening was performed. For instance, the presence of vernix and/or amniotic fluid in the neonate's ear canal in the first hours of life may lead to false-positive results ${ }^{32}$. Other justifications found in the studies were the professional's inexperience, unfavorable conditions (such as excessive environmental noise), or even the newborn's health condition ${ }^{16,18}$. These data reinforce the need for scientific discussions on the difficulties faced nationwide, to achieve better results in the UNHS programs and minimize the effects on the health system.

The literature also highlights the importance of adhering to the UNHS, including the retest cases, to decrease the absenteeism rates ${ }^{2,3}$. In the present review, 
the nonattendance rates ranged from $0 \%$ to $38.8 \%^{11-27}$ (Figure 1), whose main causes were the distance from the place where the exam is conducted, unawareness of the importance of the retest, the newborn was not the first child, single mothers, mother's low schooling level, nonadherence to prenatal care ${ }^{33}$.

Factors that can contribute to a better adherence include making the parents and other mother-child health professionals aware of the importance of the exam, as well as implementing efficient tracking programs to bring back newborns who have not yet completed all the UNHS stages ${ }^{20}$.

Regarding the percentage of satisfactory retest results, the studies showed a greatly disparaging variance, ranging from $96 \%$ to $13.33 \%^{11-27}$ (Figure 1). In the screening services with high "pass" rates in the initial stage, the number of "fails" in the retest was higher, which shows the effectiveness of the initial stage. On the other hand, in the programs with high "fail" rates in the initial stage, the "pass" rates in the retest were higher, which reveals the frailty of the initial stage.

The percentage of unsatisfactory results in the first UNHS stage ranged from $1.5 \%$ to $41 \%^{11-27}$. As for the retest stage, the rates ranged from $4 \%$ to $86.67 \%{ }^{11-27}$. Despite the discrepancies between the results from the studies, all the neonates with a "fail" outcome in the retest were referred for full auditory assessment.

The recommendation is that only $4 \%$ of those who performed the UNHS be referred for diagnosis ${ }^{2,4}$. Hence, of the 12 articles that reported this percentage, 10 achieved the goal - which shows the efficiency of the programs, and consequently the distribution to decrease its costs.

Not all the studies reported the identified cases of hearing loss; when they did, the proportion was not more than $1.97 \%$ (Figure 1$)^{11-27}$. The precariousness of this information oftentimes is because the services which perform the UNHS do not continue the assessment in cases of "fail". These children are referred to auditory health reference centers for audiological diagnosis and intervention ${ }^{11-27}$. Furthermore, the diagnosis data are not passed on to the institutions that conducted the UNHS, which explains the absence of this information in most of the articles. Nevertheless, such information is essential to the programs, as it promotes an integrated health care network. Hence, the individual would be followed up in various health care levels according to the specificities, with no interruption. Also, it would encourage the adherence of health professionals to the referral and counter-referral system, which consequently improves the communication between the sectors and ensures the patient a comprehensive treatment.

The law enforces that the evoked otoacoustic emission exam be performed for free in every child born in a hospital or maternity. Nonetheless, it has not yet been fully complied with. Such compliance is necessary because it puts epidemiological surveillance in perspective regarding the hearing loss in neonates, leading to knowledge about the situation of neonate auditory health at the municipal, state, and federal levels. Also, it enables decentralized and democratic programs and auditory health promotion actions to be planned based on local needs.

It has been almost 10 years since the law $12,303 / 2010$ on the nationwide obligatoriness of the UNHS was passed - however, the country has not yet reached many of the internationally proposed quality indicators. This is a truly relevant piece of information, which reveals that having a law is not enough for it to be put into effect. The basic instruments and resources must be made available to implement the National Neonatal Hearing Screening Program. The path to progress in the national scenario regarding the UNHS programs passes through the constant search for improvements in the current programs. Also, it requires inspections of the procedures performed, as well as the regulation of the current laws to ensure the best development of the person's potentials. These would contribute to their well-being and consequently to more effective inclusion in the society.

\section{CONCLUSION}

Given the results, it was concluded that throughout the years that followed Law 12,303/2010 and its obligatoriness, the South and Southeast Regions concentrated most of the UNHS programs. Also, the evoked otoacoustic emissions technique was the main procedure employed.

The studies achieved two goals regarding the quality indicators, namely: the rates of UNHS performed within the first month of life, and satisfactory diagnosis referrals. However, the coverage rates are still below the expectation and there are still high retest referral indexes, much absence of neonates in the subsequent stages, low rates of satisfactory retest results, and a large number of "fail" in both screening stages.

There are still many challenges to reach these quality indicators in Brazil. It is crucial to invest in 
strategies that aiming at continuing the assistance and promoting the early intervention stage for all the children presented with hearing loss.

\section{ACKNOWLEDGMENT}

Gratitude is extended to the Faculdade de Medicina de Botucatu and the Universidade Federal de Santa Catarina for their technical support.

\section{REFERENCES}

1. Yoshinaga-Itano C. Levels of evidence: universal newborn hearing screening (UNHS) and early hearing detection and intervention systems (EHDI). J Commun Disord. 2004;37(5):451-65.

2. American Academy of Pediatrics $\mathrm{JCIH}$. Year 2007 Position statement: principles and guidelines for early hearing detection and intervention programs. Pediatrics. 2007;120(4):898-921.

3. Lewis DR, Marone SAM, Mendes BCA, Cruz OLM, Nóbrega M. Multiprofessional committee on auditory health: COMUSA. Braz J Otorhinolaryngol. 2010;76(1):121-8.

4. ASHA. Year 2019 Position Statement: Principles and guidelines for early hearing detection and intervention programs. J.Early Hear Detect. Interv. 2019;4(2):1-44.

5. Joint Committee on Infant Hearing 1990. Position Statement ASHA Suppl. 1991;5:3-6.

6. Olusanya BO, Newton VE. Global burden of childhood hearing impairment and disease control priorities for developing countries. Lancet. 2007;369(9569):1314-8.

7. Brasil. Ministério da Saúde. Portaria no 2073 , de 28 de setembro de 2004. Institui a Política Nacional de Atenção à Saúde Auditiva. [cited 2020 Apr 09]. Available from:http://bvsms.saude.gov.br/bvs/ saudelegis/gm/2004/prt2073_28_09_2004.html

8. Brasil. Ministério da Saúde. Secretaria de Atenção à Saúde. Departamento de Ações Programáticas Estratégicas. Diretrizes de atenção da triagem auditiva neonatal. 2012. [cited 2019 Feb 26]. Available from: http://bvsms.saude.gov.br/bvs/ publicacoes/diretrizes_atencao_triagem_auditiv neonatal.pdf

9. Brasil. Lei $\mathrm{n}-12.303$, de 2 de agosto de 2010 "Dispóe sobre a obrigatoriedade de realização do exame denominado Emissões otoacústicas Evocadas". [cited 2019 Dec 17]. Available from: http://www.jusbrasil.com.br/legislacao/1024360/ lei-12303-10
10. Pereira PKS, Martins AS, Vieira MR, Azevedo MF. Newborn hearing screening program: association between hearing loss and risk factors. Pró-Fono R. Atual. Cient. 2007;19(3):267-78.

11. Onoda RM, Azevedo MF, Santos AMN. Neonatal hearing screening: failures, hearing loss and risk indicators. Braz J Otorhinolaryngol. 2011;77(6):775-83.

12. Sabbag JC, Lacerda ABM. Neonatal Hearing Screening in primary health care and family health care. CoDAS. 2017;29(4): 1-7.

13. Januário GC, Alves CRL, Lemos SMA, Almeida MCM, Cruz RC, Friche AAL. Health Vulnerability Index and newborn hearing screening: urban inequality. CoDAS. 2016;28(5):567-74.

14. Biscegli TS, Bertoni A, Belucio IS, Marcos JMO, Matias TY, Cid FB. Neonatal hearing screening: a study of the newborns of a teaching hospital in the state of São Paulo, Brazil. Pediatr. Mod. 2015;51(6):214-9.

15. Barboza ACS, Resende LM, Ferreira DBC, Lapertosa CZ, Carvalho SAS. Correlation between hearing loss and risk indicators in a neonatal hearing screening reference service. Audiol., Commun. Res. 2013;18(4):285-92.

16. Oliveira JS, Rodrigues LB, Aurélio FS, Silva VB. Risk factors and prevalence of newborn hearing loss in a private health care system of Porto Velho, Northern Brazil. Rev. paul. pediatr. 2013;31(3):299-305.

17. Cavalcanti HC, Guerra RO. The role of maternal socioeconomic factors in the commitment to universal newborn hearing screening in the Northeastern region of Brazil. Int $\mathrm{J}$ Pediatr Otorhinolaryngol. 2012;76(11):1661-7.

18. Faistauer MA, Marquezan TA, Floriano M, Tabajara CC, Mahfuz MC, Schmidt VB et al. Implementation of a program of universal newborn hearing screening in a university hospital in a city in south Brazil: preliminary results. Rev. AMRIGS. 2012;56(1):22-5.

19. Rodrigues PAL, Carvalho TSF, Lauris JRP, Schochat E. Results of a newborn hearing screening program in Cuiabá - Mato Grosso, Brazil. Rev. soc. bras. fonoaudiol. 2011;16(4):454-8.

20. Botelho MSN, Silva VB, Arruda LS, Kuniyoshi IC, Oliveira LLR, Oliveira AS. Newborn hearing screening in the Limiar Clinic in Porto Velho - Rondônia. Braz J Otorhinolaryngol. 2010;76(5):605-10. 
21. Lima MC, Rossi TR, Françozo Mde F, CollelaSantos MF, Correa CR. Analysis of neonatal hearing screening program performed on an outpatient basis: analysis of an outpatient hearing screening program. Int J Pediatr Otorhinolaryngol. 2015;79(12):2227-33.

22. Kemp AAT, Delecrode CR, Silva GC, Martins F, Frizzo ACF, Cardoso ACV. Neonatal hearing screening in a low-risk maternity hospital in São Paulo state. Braz J Otorhinolaryngol. 2015;81(5):505-13.

23. Silva GC, Delecrode CR, Kemp AT, Martins F, Cardoso ACV. Transient evoked and distortion product otoacoustic emissions in a group of neonates. Int Arch Otorhinolaryngol. 2015;19(3):255-8.

24. Silva DP, Lopez PS, Ribeiro GE, Luna MO, Lyra JC, Montovani JC. The importance of retesting the hearing screening as an indicator of the real early hearing disorder. Braz J Otorhinolaryngol. 2015;81(4):363-7.

25. Januário GC, Lemos SMA, Friche AAL, Alves CRL. Quality indicators in a newborn hearing screening service. Braz J Otorhinolaryngol. 2015;81(3):255-63.

26. Lupoli Lda M, Garcia L, Anastasio AR, Fontana AC. Time after birth in relation to failure rate in newborn hearing screening. Int $\mathrm{J}$ Pediatr Otorhinolaryngol. 2013;77(6):932-5.

27. Bevilacqua MC, Alvarenga KF, Costa OA, Moret AL. The universal newborn hearing screening in Brazil: from identification to intervention. Int $\mathrm{J}$ Pediatr Otorhinolaryngol. 2010;74(5):510-5.

28. Cadastro Nacional de Estabelecimentos de Saúde [home page on the Internet]. Brasília: CNESNet Secretária de Atenção à Saúde, [acesso em 2019 Feb 26]. Disponível em: http://cnes2.datasus.gov. br/Mod_Ind_Especialidades.asp?VEstado $=17 \&-$ VMun $=\&$ VComp $=00 \&$ VTerc $=00 \&$ VServico $=107 \&$ $\mathrm{VClassificacao}=006$

29. Paschoal MR, Cavalcanti HG, Ferreira MAF. Spatial and temporal analysis of the coverage for neonatal hearing screening in Brazil (2008-2015). Ciênc. saúde coletiva. 2017;22(11):3615-24.

30. Kalichman AO, Ayres JRCM. Comprehensiveness and healthcare technologies: a narrative on conceptual contributions to the construction of the comprehensiveness principle in the Brazilian Unified National Health System. Cad. Saúde Pública. 2016;32(8):1-13.
31. Cavalcanti HG, Melo LPF, Buarque LFSFP, Guerra RO. Overview of newborn hearing screening programs in brazilian maternity hospitals. Braz $\mathrm{J}$ Otorhinolaryngol. 2014;80(4):346-53.

32. Melo ADP, Duarte JL, Alvarenga KF, AgostinhoPesse RS, Bevilacqua MC, Martinez MAN. Influência do tempo de vida na pesquisa das emissões otoacústicas evocadas transientes em recémnascidos. Distúrb. Comun. 2007;19(3):357-64.

33. Fernandes JC, Nozawa MR. Effectiveness study of the universal newborn hearing screening. Ciênc. saúde coletiva. 2010;15(2):353-61. 